\title{
How Corrupt Are Universities? Audit Culture, Fraud Prevention, and the Big Four Accountancy Firms
}

\author{
by Cris Shore
}

\begin{abstract}
Corruption narratives, like witchcraft accusations, offer a lens for analyzing social relations, economic interests, and hidden structures of power. Developing this theme, I examine discourses of corruption in the context of growing concerns about fraud prevention and anti-corruption in universities. Moving beyond critiques of university administrations as bureaucratic, self-serving entities whose interests are increasingly antithetical to the academic mission of the university, I ask, What is corruption in academia and how does this assumed problem relate to academic capitalism and the rise of audit culture? The empirical context for my study is the extraordinary increase in institutionalized fraudprevention programs, particularly those offered by the "Big Four" accountancy firms. Taking as my case study the introduction of a whistle-blower hotline at one Australasian university, I examine the politics and interests behind such schemes. The increasing involvement of accountancy firms in nonauditing work, including anti-corruption services, illustrates how corruption narratives operate as market-making strategies. I examine how commercialization, risk management, and auditing proliferate anti-corruption initiatives and how audit firms collude in the risk and corruption that they claim to ameliorate. I conclude by assessing the implications for the anthropology of corruption of the growing penetration of universities by an increasingly commercially focused tax industry that, some argue, cannot even be trusted to regulate itself.
\end{abstract}

Neoliberalized Universities and the Growth of Corruption

Over the past decade, concerns about rising corruption have spread to one of the world's oldest and most hallowed institutions: the university. However, given the difficulties of studying corruption, let alone measuring it, the question of how corrupt universities are is not one we can answer with any accuracy. As Philip Altbach (2015:7) observes, despite the plethora of indicators for measuring and ranking universities by the quality of their research and teaching, credit ratings, reputation, and other factors - such as impact, innovation, graduate employability, and the student experience- " "no one has developed a worldwide academic corruption index." Not yet, at least. Rather than assessing whether universities are becoming more corrupt or what indicators might serve to measure and corroborate such claims, I use these questions to interrogate two broader conceptual issues. The first is the "performativity" of the word corruption, or how it is put to work, particularly given the difficulties of defining what constitutes corruption in academia. My use of

Cris Shore is Professor of Social Anthropology at the Faculty of Social Sciences, University of Auckland (10 Symonds Street, Auckland 1010, New Zealand [c.shore@auckland.ac.nz]), and at the Stockholm Centre for Organisational Research of Stockholm University (SE-106 91 Stockholm, Sweden). This paper was submitted 6 IV 17, accepted $1 \mathrm{XI} 17$, and electronically published 16 II 18. the term performativity draws on the idea of "speech acts" developed by anthropologists and philosophers of language (Austin 1962; Butler 1997; Turner 1988), who argue that the work of speech and communication is not simply to communicate but also to consummate action. In this sense, narratives about university corruption work to legitimize forms of action, empower certain individuals - typically accountants, risk managers, and anti-corruption experts - and bring particular kinds of social reality into being. This is also what Ian Hacking (2002: 108) termed "dynamic nominalism"; the way social classifications create new categories of problem and subjectivity.

The second issue concerns the major changes in the organization of universities over the past two decades as a result of successive waves of neoliberal reform that most Organization for Economic Cooperation and Development (OECD) countries have implemented over that time and the problems that these changes raise for combating corruption. These reforms have resulted in a growing marketization of the university and have introduced a raft of new forms of accountability and control based on principles of financial accountancy and new public management. Their initial aim was to introduce economic and administrative efficiencies into the governance of academia, promoting innovation and entrepreneurialism. But this "enterprise university model" (Marginson and Consadine 2000)—what Slaughter and Leslie (1997) labeled "academic capitalism"- has produced both new opportunities and new 
cleavages. More important, these changes also reflect the rise of "audit culture" (Power 1997; Strathern 2000). The term audit culture refers to the way that the techniques, practices, and rationalities of accountancy have expanded beyond the domains of finance to become major principles of organization and instruments of management throughout both public- and private-sector organizations (Shore and Wright 2015). Audit culture is an assemblage of different policy processes, accounting technologies, and moral injunctions that exert power through the normalization and naturalization of particular ways of thinking and financialized forms of management. In academia, audit culture reaches down from government officials, university leadership teams, and faculty managers to heads of schools, departments, and individual academic staff in ever-more pervasive drives to measure and improve staff productivity and performance (Shore 2008; Shore and Wright 1999).

The extent to which academic capitalism has led to increased corruption is debatable. However, two recent reports by the United Nations (UN) Educational, Scientific, and Cultural Organization (UNESCO; Hallak and Poisson 2007) and Transparency International (2013a) argue that corruption in higher education has become a matter of mounting international concern for governments, educators, students, and other stakeholders. It is also a growing problem in China, where some have described it as a "cancer" (Yang 2015). Corruption in universities is not a new phenomenon, but what is new, according to Chapman and Lindner (2016:247), is a "unique convergence of pressures that is creating heightened threat to the integrity of the higher education enterprise worldwide." Transparency International (2013b) identifies four factors creating the conditions for corruption to flourish. First, declining public funding for higher education and the erosion of salaries. Second, a corresponding emphasis on universities generating their own income streams, often by raising tuition fees, increasing pressure on academics to win external grants and commercialize the results of their research, or developing for-profit auxiliary businesses, including real estate speculation. Third, an intensification of pressures on academics to publish their research in top-tiered journals as universities seek to raise their national and international standing and reputation by improving their position in world university rankings. And finally, the expectation that universities should generate their own funds has resulted in institutions being granted far greater administrative autonomy. To these, we might add a fifth factor: by weakening state controls and established regulatory practices, neoliberal policies have opened up "vast extralegal spaces of opportunity for appropriation and influence" (Muir 2016:135; see also Comaroff and Comaroff 2006). In a climate of budget cuts and increasing competition for status and resources, these trends have encouraged more "flexible" approaches to bending the rules and interpreting what constitutes acceptable practice (Chapman and Lindner 2016:47). As Heyneman observes:

Competition for resources, fame and notoriety place extraordinary pressures on higher education institutions. The weaker ones, those with an absence of control or managerial strength, are most prone to corruption. In some instances, corruption has invaded whole systems of higher education and threatens the reputation of research products and graduates regardless of their guilt or innocence. (Heyneman 2013:101)

According to the director of UNESCO's International Institute for Education, academic fraud has become so widespread that it now poses a "serious threat" to public trust in educational institutions and performance and to the "integrity and reliability of certification of higher education" (Hallak and Poisson 2007:3).

In this article, I consider these pressures and reflect on how debates about corruption in higher education are being framed. I also question the assumptions about the causes of corruption, including the oft-repeated argument that "the roots of corrupt practices lie in a lack of transparency and accountability" or the absence of "strong management" (Transparency International 2013b:xiii). Moving beyond questions of how corrupt universities are, I examine the interests behind efforts to combat corruption in academia. Discourses about the dangers that corruption poses to public trust in universities, I argue, are both instrumental and performative, not only serving internal managerial agendas but also creating ways to open universities up to external financial interests and for-profit service providers. Paradoxically, many of the problems that the Transparency International nongovernmental organization and anti-corruption agencies identify, including procurement fraud and collusion, are often exacerbated by the very agencies employed to combat such practices. If the same logics that fuel corruption are also driving anti-corruption programs, where does this leave the future of the university?

My argument is set out in four parts. First, following brief remarks about anthropological approaches to corruption, I take up Roscigno's provocative idea of looking at university administration as a new form of organized crime (2015). While Roscigno's comparisons are largely rhetorical, I suggest that they nevertheless highlight significant trends arising from the increasing power that has accrued to university managers and senior administrators. These trends illustrate how risk and audit have become prevalent themes in university governance, replacing previous notions of public management and professional integrity. I also consider the question of defining corruption in the university context and reflect briefly on different varieties of academic corruption. Second, drawing on fieldwork in New Zealand, I describe one university's attempts to combat corruption by introducing a whistle-blower hotline. Tracing the history of this and similar initiatives across Australasia, I ask what drives these programs and what they reveal about the effects of corruption narratives. As I illustrate, the "Big Four" accountancy firms play an increasingly dominant role in the burgeoning anti-corruption services market - a market that these firms themselves have helped to create. However, as the third section shows, these firms have lamentable records in terms of 
their own involvement with fraud, raising serious questions about collusion and conflicts of interest. Finally, I conclude by considering the effect of increasing university commercialization and institutionalized antifraud initiatives and what this reveals about audit culture's impact on the university's mission.

\section{Anthropology, Corruption, and Anti-corruption}

Anthropological approaches to the study of corruption have typically highlighted two important methodological points. The first is that corruption is neither a stable nor a universal category and that its meanings, and the behaviors that people call "corrupt," vary cross-culturally. This makes corruption hard to define and harder still to measure or compare. Transparency International's highly influential Corruption Perceptions Index is not objective but subjective: what it measures are simply the impressions ("perceptions") of individuals and experts around the world that Transparency International selects for its survey (Whyte 2015:4). Moreover, public perceptions about corruption in particular countries are themselves often shaped by Transparency International's own Corruption Perceptions Index in a self-reinforcing feedback loop. Institutional definitions of corruption are therefore often both narrowly focused and ethnocentric. This is particularly evident in the World Bank's (1997) definition of corruption as "the abuse of public office for private gain." Every way of seeing is also a way of not seeing, and this definition, by confining corruption to the public sector, effectively rules out corruption as a problem for the private sector, which has significant implications when it comes to institutionalizing anti-corruption initiatives.

The second point is that discourses about corruption and its solution provide a useful anthropological lens for analyzing wider social structures and cultural relations. Like witchcraft accusations, corruption narratives reveal a great deal about social tensions and the normative order of a society: what it considers ethical/unethical, moral/immoral, or legal/illegal (Haller and Shore 2005; Muir 2016). Social norms become most visible in moments of transgression, or as Parkin (1985) noted in The Anthropology of Evil, morality is most clearly seen in its transgression. ${ }^{2}$ In this respect, and to paraphrase Lévi-Strauss, corruption is "good to think with": while the analysis of corruption may not produce any definitive answers or solutions, like myth, it can reveal some of the fundamental dilemmas and contradictions that underlie any social system.

1. This flawed and partial definition is echoed by Hallak and Poisson (2007:29): "Corruption in the education sector can be defined as 'the systematic use of public office for private benefit." In the post-Enron era, however, some organizations, including Transparency International, have expanded the definition to include the "abuse of entrusted power" - and an entrusted power could include private as well as public organizations.

2. See also Parkin's commentary on Csordas's essay on "Morality as a Culture System," where he writes, "If you want to study happiness, then start with misery. Similarly, the entry points for a study of morality are its negative aspects" (Csordas et al. 2013:538).
"University Bureaucracy as Organized Crime": Administrative Capture and Institutionalized Rent Seeking

One inspiration for this article was a polemical article in the journal CounterPunch titled "University Bureaucracy as Organized Crime," written by Vincent Roscigno (2015), a professor of Sociology at Ohio State University. Roscigno engages in what he calls a "sociological thought experiment" to ask whether the "administrative bloating of public universities and the harm it has caused (is) akin to organized crime." Admitting that this seems far-fetched, he points out four troubling yet intriguing similarities:

1. the hierarchical, bureaucratic, and coordinated structure of both;

2. the accruing of riches at the top among a bloated cadre of high-level senior managers who sometimes set their own reward structures with little constraint or accountability to faculty or their increasingly indebted students, and who abide by the logic that higher education is but a commodity to be sold to customers through eye-candy, window-dressing investments in buildings, cafeterias, sports grounds, and high-visibility athletics programs;

3. the way both require explicit or tacit governmental support from politicians whose policies are complicit in creating these changed circumstances; and

4. the extraction of income from-and ultimate harm done to-well-intentioned families, adjunct lecturers, and the intellectual mission of public higher education.

These processes, he concludes, ultimately erode the intellectual and engagement goals on which higher education was founded. Indeed, in lieu of hiring new faculty to replace retiring faculty or building on intellectual strengths, the university bureaucrat's solution to budgetary issues now centers, more often than not, on the hiring of those in research areas flush with grant money - of which universities want a sizeable cut (Lewis and Shore 2017) _ or cheaper and all-the-more-exploitable adjunct lecturers, who typically hold $\mathrm{PhDs}$ but are underpaid, have limited benefits, and receive only temporary contracts.

This is not "corruption" as conventionally understood (i.e., bribery, embezzlement, deliberate deception, fraud, or abuse of public office), and yet there are similarities (what Wittgenstein might term "family resemblances") with organized crime. Foremost among these is the "personal financial windfall for university presidents, provosts, and executive deansa professional class of non-teaching personnel to whom the rewards and power of today's university bureaucracies increasingly accrue" (Roscigno 2015; see also Shore and Wright 2017). Another point of comparison is the emphasis placed on capturing rents and the ruthless breaking up of higher education to release its revenue-making potential: that is, these processes all entail opening up universities so that business and commercial interests can appropriate their assets- 
what Barber, Donnelly, and Rizvi (2013) call "unbundling” the university.

Many academics would view such practices - including university administrations taking a large percentage of research grants to cover "overheads" or allowing confidentiality agreements on industry-sponsored research - as forms of corruption insofar as they constitute abuse of the purposes for which those funds were intended. The point, however, is that most of the policies and practices associated with university commercialization conveniently sidestep the definitional issue of what constitutes corruption; that is, technically speaking, such actions cannot be corruption proper ("abuse of public office for private gain") because the public-private distinction is blurred. Just as universities have become repositioned as transnational business corporations operating in a competitive global knowledge economy (Wright and Shore 2017), many British, Australian, and New Zealand universities now set individual financial performance targets for external grant revenue that each academic is expected to raise as part of their job description (Grove 2015). Academic entrepreneurship that generates new income streams for the university has not only become a contractual duty; university managers now increasingly define private or commercial funding as a "public good" (Amsler and Shore 2015).

\section{Varieties of Corruption in Higher Education}

Corruption in higher education manifests itself in numerous forms including bribery, embezzlement, fraud, extortion, favoritism, nepotism, cronyism, ghost teachers, unauthorised tutoring, unfair promotions, misuse of public property, research misconduct, cheating, and plagiarism. (Osipian 2009:183)

While the risks of corruption in universities may appear obvious, its complex manifestations make definitions problematic, as Osipian (2009) suggests. Certainly universities are prone to fraud and corruption. In the 1980s, I worked in an Italian university and experienced directly Italy's entrenched system of clientelism, or raccommandazione (Zinn 2001), and the scams and ingenious practices that people deploy to bypass bureaucratic hurdles. Cheating and rorting, I discovered, were considered the norm (Shore 1989). ${ }^{3}$ The market rates for writing and translating someone else's thesis or sitting their examination were virtually public knowledge. Giving publicsector jobs to relatives, clients, or supporters was so pervasive that it hardly registered as illegal or immoral (Day 2011). But what I found particularly pervasive was a different kind of corruption, one based on institutionalized forms of clientelism in hiring, promotions, and assignments, and a division of spoils along party-political lines, or what was termed lottizzazione (Perotti 2008).

3. "Rort" is a term common in Australia and New Zealand that means to engage in fraudulent and dishonest acts, or sharp practices, while remaining within the letter of the law.
These practices, hardly unique to Italy, appear to be equally widespread in Russia, the Ukraine, and other former Soviet states (Osipian 2008, 2009), albeit in a slightly different form. However, to the best of my knowledge, endemic nepotism, family fiefdoms, and a sophisticated market in the sale of $\mathrm{PhD}$ dissertations are not problems that trouble New Zealand or its university system - although here, too, the politics of biculturalism and the growing emphasis on commercialization often result in university jobs being awarded in ways that are sometimes far from fair or transparent (Lewis and Shore 2017).

\section{Combating Fraud in the University: An Antipodean Case Study}

Rather than tackling the ontological question of "what is" university corruption or measuring whether it is increasing, I want to take a different angle by asking why universities have become so concerned with combating fraud and corruption and what lessons these anti-corruption initiatives offer for the anthropology of corruption. To address these questions, I draw on an ethnographic vignette from one of New Zealand's leading universities.

One Wednesday morning, in June 2010, I opened my university mailbox to find a curious object sent to me - and to all staff - by what I assumed was the university's human resources or communications office: a three-sided cardboard pyramid, each side displaying a message from the university senior leadership team about some recently launched initiative (fig. 1). On one side was a photograph of cigarette smoke curling sinuously from an ashtray against a black background, on top of which was written, in bold white capitals: "No Butts About It-Smoke Free Campuses." This also announced, for those who wished to kick the habit, that help was available through the university's "Quitline." The second side, this time in softer, lowercase green lettering, was an announcement about the university's new sustainability and environment policy and website:

Did You Know? In 2009, our university used 44\% less energy and $73 \%$ less water per student than 30 years ago. Please help us keep improving.

- Turn off all unnecessary lights

- Report all leaks and dripping taps

It also encouraged staff to seek further information from the university's sustainability and environment portal. ${ }^{4}$

The third side of the pyramid showed a man in a suit speaking into a mobile telephone, over which was written, in red and white, "FairCall" and "Let's protect our University." Full of imperatives and injunctions, this announced a new antifraud

4. Somewhat controversially, the vice chancellor later dismissed as contrary to the interests of the university a campaign led by academics and students that sought to implement a policy of university disinvestment in fossil fuel companies. 


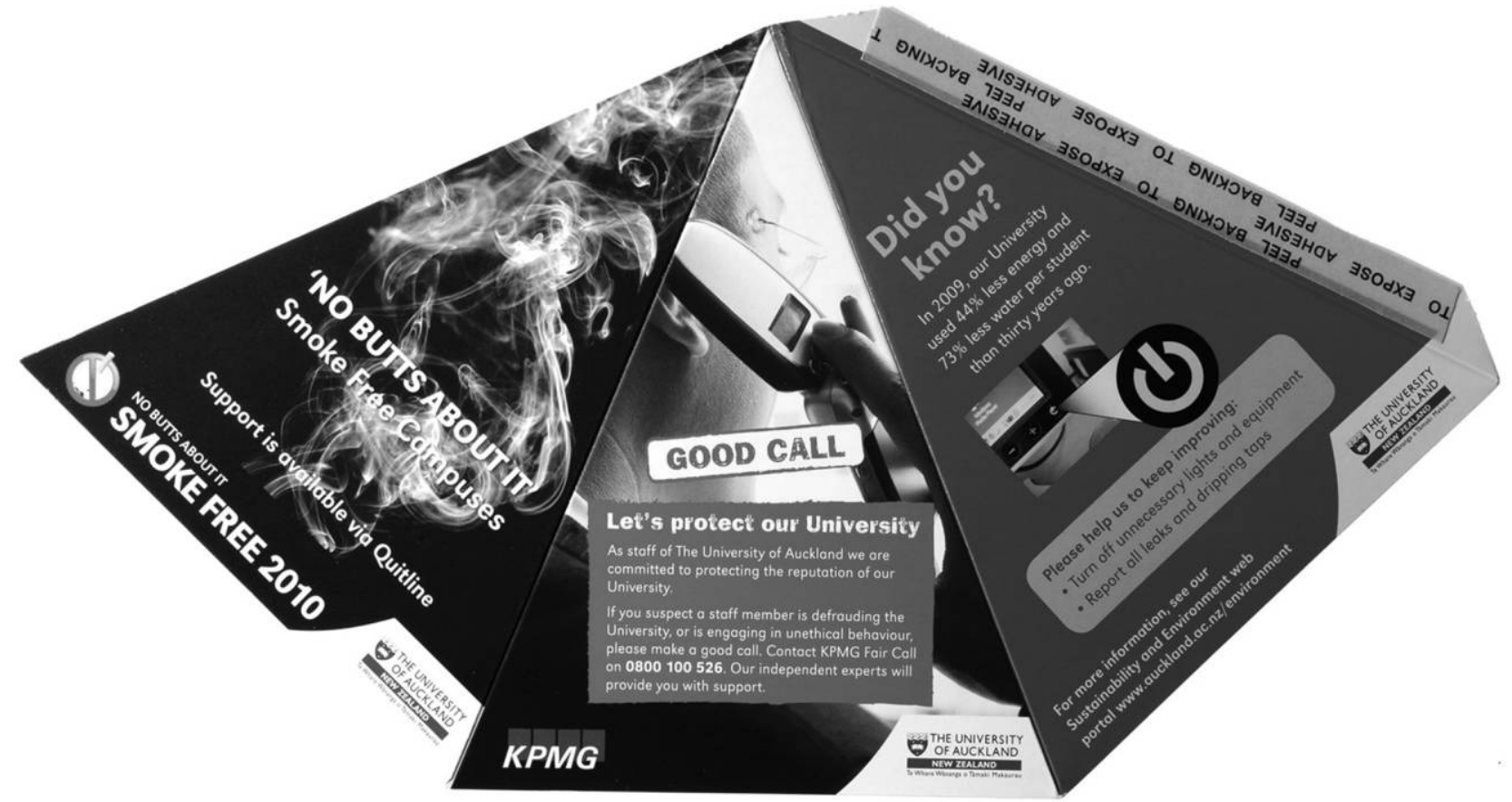

Figure 1. Office "desk pyramid" sent to all University of Auckland staff in 2010 announcing three new policies, including the FairCall whistle-blower hotline. (Photograph by Tim Mackrell.) A color version of this figure is available online.

and anti-corruption initiative, asserting that, "As staff of The University of Auckland we are committed to protecting the reputation of our university. If you suspect a staff member of defrauding the university, or of engaging in unethical behaviour, please make a good call. Contact KPMG FairCall on 0800 100 526. Our independent experts will provide you with support."

Why had Auckland University launched this new antifraud hotline? What was the context behind this initiative? Had the university suddenly become more exposed to corruption? And why was the telephone hotline being directed by KPMG - an international accountancy firm not particularly recognized for its expertise in either anti-corruption or higher education? I decided to investigate.

\section{Measuring Fraud or Market Making?}

Tracking through the archives, I found a Radio New Zealand Newswire press release dated February 15, 2010, announcing that "the accounting firm KPMG says fraud in New Zealand has risen to record levels." Fraud in New Zealand, it added, "amounted to 100-million dollars in 2009, with a dramatic surge in the second half of the year" (Thompson 2010). Further news reports in the Independent Financial Review and Fairfax Media highlighted more alarming figures:

Fraud soared in the second half of 2009, boosting the amount defrauded for the year to $\$ 100 \mathrm{~m}$, but the worst is yet to come, KPMG says. In the six months to December, $\$ 76 \mathrm{~m}$ was de- frauded compared with $\$ 22$ in the first half of the year, according to KPMG's large-scale fraud survey. . . . KPMG forensics partner Mark Leishman said the jump in the second half of last year was due to several multimillion dollar cases. Businesses had kept a closer eye on their books, meaning fraud was more likely to be detected. (Independent Financial Review 2010)

For a country that prides itself on its reputation for being one of the world's least corrupt and most transparent countries, these figures are worrying. The only mitigating factor was that the high levels of fraud, most of which had been perpetrated against the government, financial institutions, and commercial businesses, had been uncovered during the 2008 global financial crisis and therefore reflected preexisting frauds. However, KPMG warned that "these figures confirm that fraud is a constant and serious threat to all sectors of the New Zealand economy, including business, governments, non-profit organisations, and individuals" (Scoop Media 2010). It also warned that the threat to organizations was as much internal as external. As the KPMG Fraud and Misconduct Survey 2010 put it, "Who did it and why? Sixty-five per cent of major frauds are committed by people already working in the victim organisation, who usually act alone" (KPMG 2010:3).

As if to corroborate this, the KPMG "Fraud Barometer," released in July 2010, was headlined by Radio New Zealand National as "Fraud expected to rise to record level." Yet according to KPMG forensic expert Stephen Bell, these figures were "only the tip of the iceberg" (McEntee 2010). The lobby 
group Business New Zealand (RNZ 2010) echoed the warning. To monitor these trends, KPMG began publishing the biannual Fraud Barometer, the findings of which are based on reported fraud cases brought before the criminal courts. These reports drew the same conclusions: fraud was a serious problem for both public and private sectors, the threat of fraud was growing, and the main perpetrators were individual employees - or as one report put it, "98 per cent by value were 'inside jobs"” (KPMG 2010:3). The other key message is that most companies are complacent and do not spend enough on fraud and corruption prevention or detection. ${ }^{5}$

The following year, KPMG's fraud detection activities again made headline news: "KPMG says more fraudsters are being caught in New Zealand," announced a Radio New Zealand bulletin, noting that KPMG's 2011 Fraud Barometer had identified "20 high value fraud cases in the six months to December, almost a third more than in the first half of the year" (RNZ 2011). The 2012 Fraud Barometer reported an even more dramatic increase: financial crime had now reached a record $\$ 1.7$ billion, $\$ 279.7$ million of which arose directly from fraud, including four "super-frauds" - a term used for frauds greater than $\$ 3$ million (KPMG 2012a). For KPMG, the lesson was obvious:

The message from experts, well supported by the results of this survey, is clear. To mitigate the risks of fraud, bribery and corruption, all New Zealand organisations need to plan for, implement and/or improve their prevention, detection and response strategies. Seen in this light, the opportunity to offer a dedicated analysis of the New Zealand experience is thus timely and important. (KPMG New Zealand 2012)

The same year, Deloitte (2012) commissioned its own Bribery and Corruption in Australia and New Zealand Survey, menacingly subtitled "A Storm on the Horizon." And in 2014, PriceWaterhouseCoopers (PwC) published its global Economic Crime Report, subtitled "What you don't know can hurt you," which included a 32-page New Zealand supplement (PwC 2014). The Deloitte report was based on a survey of 390 respondents, most of whom are employees of Australian subsidiaries of foreign companies, public sector organizations, and financial organizations involved with compliance, risk, legal, and internal auditing. Like the KPMG report, it revealed a dramatic increase in fraud, warning of more to come and criticizing Australasian organizations for their complacency. To emphasise the point, it included a large boxed quote from Nick Peterson of the New Zealand Serious Fraud Office:

It would be easy to sit back and say that New Zealand is the country perceived to have the least corruption, and that it

5. It should be noted that fraud is not corruption, technically speaking. Fraud typically entails false representation, deception, or concealment for personal pecuniary advantage. Where this develops into corruption is in situations where officials or managers attempt to cover up, protect, or collude with a fraudster. I am grateful to Steven Sampson for highlighting these distinctions only happens to others. However, we are seeing more instances of domestic corruption, such as bribes paid to public officials, and corrupt payments made within the private sector. Organisations need to be awake to the changing environment as well as the legal and reputational risks and consequences associated with engaging in corrupt practices. (Deloitte 2012:25)

The Deloitte report's recommendation was that organizations needed to conduct more regular bribery and risk assessments. Like the KPMG surveys, Deloitte also framed its report around metaphors of risk and protection, comparing fraud to a dangerous hurricane (as opposed to a treacherous iceberg), requiring urgent action to protect institutions (and "build resistance to flawed decision making"). And who better to do that work than professional risk-management accountants at Deloitte and KPMG?

These texts perfectly illustrate the performativity of corruption narratives and indicators: before these barometer surveys and audit reports, company leaders and university managers rarely considered fraud and corruption as urgent problems. Yet through these headline-grabbing findings and dire predictions, the problem is created for which these audit companies profess to be the solution. Anti-corruption has shifted from a movement to a lucrative industry (Sampson 2010), and the Big Four accountancy firms have been assiduous in cultivating the climate of risk and anxiety that has helped expand their business into new markets. Indeed, "anticorruptionism" has become integral to what Sampson (2016:83) terms "moral capitalism" and the growing emphasis companies now place on ethics and reputation as valuable company assets.

It is important to note the methodology behind the Deloitte survey. The survey "was completed by 390 respondents, including those from ASZ 200 and NZX 50 companies, Australian subsidiaries of foreign companies, public sector organisations and other listed and private companies. . . . The most common profile of respondent was a male employee within a senior financial position" (Deloitte 2012:2). ${ }^{6}$ In short, these estimates of financial risk are derived primarily from the perceptions of those whose livelihoods are most closely entangled with risk and financial management.

\section{Genealogy of the Whistle-Blower Hotline}

How has this apparent surge in fraud impacted on New Zealand's universities? The University of Auckland's "FairCall" anti-corruption hotline was initiated in June 2010, 4 months after the KPMG report had discovered fraud to be a significant and growing economic problem for Australia and New Zealand. The report noted that the likelihood of fraud increases with the size of an organization, an important factor given that Auckland University employs over 5,000 people and has an

6. ASZ 200 and NZX 50 are the main Australian and New Zealand stock market indexes, respectively. 
operating budget of over $\$ 1$ billion NZD, making it one of New Zealand's largest organizations.

The whistle-blower hotline was in response to the Auditor General of New Zealand's (2012) guidelines on measures for the prevention of fraud. It was also part of the university's overall fraud-prevention program, overseen by the university council's audit and risk committee. As an internal university website explains:

Hotlines such as the FairCall service are now a routine part of fraud prevention programmes in most large public and private organisations. They are one of the most common means by which fraud is detected, and often allow that detection to occur earlier than would be possible through routine checks and controls. Staff might not feel comfortable reporting their concerns to their immediate manager or a more senior manager but are able, through the hotline, to make an anonymous report to KPMG. (UoA 2014)

The rationale for using an external and private company to oversee this process was purportedly for reasons of confidentiality and trust: "The KPMG FairCall service provides all University staff with an independently monitored, external and anonymous service to report any concerns they may have about behaviour or conduct, which they think might be fraudulent, deceptive or unethical" (UoA 2014).

The university's staff website notes that the FairCall hotline has generated about 10 calls per annum since its inception, "each of which has been investigated and a report provided to KPMG to then be shared with the caller" (UoA 2014). Fortunately, it concludes, investigations to date have not identified fraudulent activity at the university. However, this is immediately qualified with a warning that "in several instances, it has been noted that the University could implement better procedures and in others, better communication" (UoA 2014). It ends with advice to whistle-blowers about where to send their anonymous information and includes a postal address marked "KPMG Forensic, PO Box H67, Australia Square, Sydney."

Interestingly, the university's definition of corruption is far more expansive than that of the World Bank or Transparency International. As its Prevention of Fraud and Corruption Policy states:

The terms "fraud" and "corruption" are not restricted to monetary or material benefits. Fraud and corruption typically involve a deliberate, dishonest, deceptive and unauthorized act or omissions causing loss or disadvantage to the University or resulting in a direct or indirect personal gain or advantage. Corruption is dishonest activity in which a manager, staff member or contractor of the University acts contrary to the interests of the University and abuses his/her position or trust in order to achieve some personal gain or advantage for him or herself of for another person or entity. (UoA 2010)

In short, anyone acting dishonestly and "contrary to the interests of the University" could be liable to accusations of corruption. As the document notes, under these terms, even the university itself could be accused of corrupt conduct. "We've been both relieved and pleased," one senior leadership team member told me, "that we have not had misuse of the hotline with malicious calls" (personal communication, 2015). However, who constitutes "the University" or what "its" interests might be are not specified. Is the university its academics, professional staff, alumni, and students or its senate, library, and academic board? Is it a corporation sole or aggregate? Or is it embodied in the figures of its vice chancellor and senior leadership team? In New Zealand, these are issues of ongoing contestation between academics and management (Shore and Taitz 2012).

Paradoxically, the preoccupation with risk and reputation management may actually undermine the aims of the FairCall policy, as fears about proliferating risk create a climate of mistrust and bureaucratic closure. For example, in conducting research for this article, I contacted members of my university's Tertiary Education Union (TEU) branch by email to ask whether any colleagues would like to share their experiences of using the whistle-blower hotline. The following morning, shortly after 9:00 a.m., 12 hours after sending my email, the university's research ethics processes team leader (a role I had never heard of before) emailed to inform me that "a staff member forwarded your email to the Chair of University's Human Participant Ethics Committee (UAHPEC) to ask whether my research had UAHPEC approval." I was politely informed that formal ethics approval was required if I wished to solicit information of this kind. Obtaining UAHPEC approval is an arduous process that typically involves completing a 30-to-40-page application form plus numerous appendices (including participant information sheet, consent forms, and sample questions) and usually requires several attempts - and many months - before approval is granted. Many of my colleagues saw this as a crude attempt to shut down my research. One colleague even telephoned me that evening and warned that I should issue a retraction; otherwise, I risked laying myself open to disciplinary action. "They can be pretty vicious if they want to," he added, drawing on previous experience. I therefore sent another email to the TEU mailing list asking colleagues to ignore my previous email because I did not have UAHPEC permission to conduct this enquiry. That second email elicited many more responses, including several offers from colleagues to speak off the record about their experiences of fraud, corruption, nepotism, and bullying. One of the reviewers for this article suggested that I make this incident the central theme of this article. As they summed up the story, "Academics whose skill set it is to interview and ferret find it very difficult to do so, even on their own turf. This tells us a lot about why transparency for most of us, no matter what our subject position, is an illusion. Corporate entities in the age of neoliberalism generate, as a matter of routine, opacity."

Such opacity combined with mistrust leads precisely to the conspiratorial mind-sets that are integral to the corruption/ anti-corruption complex that Muir and Gupta (2018) outline in the introduction to this special issue of Current Anthro- 
pology. However, while these themes of organizational transparency and trust feature prominently in debates about audit culture and academia (Strathern 2000), my story has a different analytical intent: to understand what drives these preoccupations with combating corruption. To my surprise, one of the university's senior leadership team came to my aid by putting me in contact with the university's Performance and Risk Coordination Office and KPMG Australia. I therefore interviewed several Australian and New Zealand forensic accountants and risk management officials. What I discovered was that most whistle-blower calls were not about accounting irregularities or misappropriation of funds; rather, they concerned bullying and harassment of staff and students (see KPMG Australia 2016b). One could interpret this as evidence of the decline in university collegiality, or as evidence that people are now more likely to report workplace bullying, or perhaps both.

\section{Why This Heightened Concern with Corruption? Why Now? What Has Changed?}

A key claim KPMG and Deloitte make is that New Zealand has been complacent about fraud protection. Historically, bribery and corruption were not high on the agenda for Australian and New Zealand organizations. What has changed, however, is the international and institutional context. As Deloitte's report notes (2012:1), Australian and New Zealand organizations have become increasingly exposed to risks of fraud and bribery as they look overseas for new business and growth opportunities. The environment of austerity and economic volatility created by the 2008 financial crisis is another factor. As New Zealand's Auditor General (2012:9) acknowledges, "risk of fraud increases when many people struggle to make ends meet. Experience internationally generally confirms a greater incidence of fraud in recessionary economic climates, with fraud increasing because of 'need' rather than greed." As I illustrate below, this is a very different explanation for the causes of fraud than that given in the KPMG and Deloitte reports.

Other contextualizing factors include more stringent application of anti-bribery and corruption legislation, such as the UK Bribery Act (2010) and the growing enforcement impact internationally of the US Foreign Corrupt Practices Act, the UN Convention Against Corruption (2005), the UN Convention against Transnational Organised Crime (2003), and the OECD Convention on Combating Bribery of Foreign Public Officials in International Business Transactions (revised in 2009). It also includes the more recently established International Standards Organization antibribery standard, established by Australia. Both Australia's Federal Police and New Zealand's Serious Fraud Office have increased their enforcement of anti-corruption legislation, partly in response to the US "war on terror" and to fears about trafficking and money laundering for purposes of terrorism. ${ }^{7}$

7. As the Australian government's Attorney-General's Department (2016) declares, corruption "undermines democracy and the rule of law,
However, neither KPMG, nor Deloitte, nor PwC draws any links between increasing corruption and the policies and practices associated with the spread of audit culture and neoliberalization. By contrast, critical accountants and economists argue that taking high risks and malpractice in pursuit of profits in the financial sector are a direct consequence of the "neoliberalist faith in competition, free markets, quest for private gain and light-touch regulation" (Sikka 2015:3; Stiglitz 2010). Instead, these firms insist that individual greed, opportunity, and lack of internal controls are what drive rising levels of corruption. KPMG Australia has even produced a profile of the types of people who commit fraud. The "typical fraudster," it asserts, "is between 36 and 55," "predominantly male," holds an "executive or director-level position," is "autocratic" yet "well-respected in their organization" and "likely to be regarded as friendly," and is "motivated by personal gain" and the sense of "because I can" (KPMG 2016a; see also PwC 2014a). While their data can, no doubt, corroborate these claims, the emphasis on individual and psychological factors masks the wider structural and systemic issues. In the case of universities, the increasing exposure to risk is itself often a result of the financialization of higher education and increased levels of indebtedness as universities borrow to fund new building programs. As Transparency International (2013a) notes, increasing university fraud is closely linked to decreasing government investment:

As the global economic crisis heated up over the past few years, public money for education declined in many countries, causing some colleges and universities increasingly to depend on the generosity of private donors. . . . The very structure and culture of colleges and universities, as well as the current constraints under which many . . . operate, can create conditions that facilitate fraud. (Transparency International 2013a:114)

That said, the massive corruption found in many Eastern European state-funded universities (Osipian 2009) makes it hard to sustain the argument that privatization alone is the source of increased corruption. Transparency International also highlights the prevalence of admissions fraud in the former Soviet states. Ukrainian university administrators have become "inventive in circumventing new admissions rules in order to grant admission to their protégés," it claims, while in Russia, "paid impersonators of students have been arrested in testing centres" (Parr 2013). There is, however, another aspect of this link between decreasing public investment, increasing private involvement, risk management, and corruption that is worth pursuing further: the role of the audit companies themselves.

\section{KPMG and Deloitte: Warriors of Integrity or Agents of Corruption?}

David Whyte (2015) suggests that one reason for the recent explosion of high-profile corruption scandals in the United

as well as distorting market forces and paving the way for organised crime and terrorism." 
Kingdom-involving some of what were previously the country's most trusted institutions, like the National Health Service, the police, and Parliament - is because the watchdogs that are supposed to guard against corruption have been fatally weakened by "the slow and pernicious onward march of a neoliberal political economy" (Whyte 2015:5; see also Sikka 2014). The same international institutions that demand the removal of protective economic policies to encourage privatization and "market reform," he notes, often drive anti-corruption policies. Indeed, Peter Eigen, one of the founders of Transparency International, previously worked for the World Bank, and Transparency International maintains a close relationship with the bank today.

The Big Four international accountancy firms often portray themselves as professionals dedicated to probity and honesty, "integrity warriors" engaged in the global fight against fraud and corruption (Sampson 2005:105). But they also have a vested interest in promoting the market in the anti-corruption services that they provide. These firms, as Sikka (2015:157) observes, were "key players in establishing the post-1970s hegemony and major beneficiaries of the financialization of the economy. They have become adept at bending the rules to advance their economic interests." In short, these companies are part of the problem for which they claim to be the solution.

Between them, the Big Four employ over 750,000 staff, operate across 150 countries, and, in 2014 alone, generated a massive $\$ 113.7$ billion in revenues (Doherty 2014). These firms dominate the market in company auditing, yet what is striking today is that their fastest-growing divisions are currently in services other than auditing. Indeed, nonaudit work now accounts for over $60 \%$ of the Big Four's total global revenues. This involves a raft of legal, financial, and management services that include risk assessment, ethics and compliance, business consulting, planning, tax advice, superannuation, insurance, and even climate change and sustainability (KPMG 2016). As a result, one part of these firms might be auditing a company's books while another part provides the same client with tax avoidance advice that may include lucrative tax shelters in unregulated tax havens such as Panama, Luxembourg, or the Caribbean Islands. Ernst and Young and KPMG (but not Deloitte) responded by disposing of their consulting arms. However, by the mid-2000s, as Agnew (2015) notes, "these agreements had expired, paving the way for the firms to rebuild in consulting - under the guise of 'advisory' work - through a series of acquisitions."

As a result of these acquisitions and growth, the Big Four have pioneered a new hybrid form of business entity that is neither a multinational corporation nor a global partnership, nor even a single firm. Their role, instead, is to act as "coordinating entities" for their network of global affiliates that are unified around a brand and that adhere to shared values and ethics and a common code of conduct (Ernst and Young 2013; KPMG 2012b). This new business model was designed to make the firms more flexible and responsive to their globalizing clients and better equipped to capture new markets. However, it has also made them more vulnerable to conflicts of interest, dangerous risk taking, and fraud, as evidenced in the extraordinary number of scandals involving Big Four auditors in cases of fraud, false accounting, manipulation of share value, and tax evasion. Hence, Sikka (2015:158) notes that "an internal report by Her Majesty's Revenue and Customs (HMRC) in 2005 concluded that the Big Four accounting firms were behind almost half of all known avoidance schemes." Little seems to have changed since then, and as the House of Commons Committee of Public Accounts (2015:3) noted in a recent report, the mass marketing of complex and aggressive tax avoidance schemes by these firms constitutes "the promotion of tax avoidance on an industrial scale."

For example, KPMG failed to warn directors of the Canadian company Hollinger about violations of fiduciary standards that investigators described as "corporate kleptocracy." Between 1997 and 2003, Lord Conrad Black, its founder, managed to syphon off a staggering $\$ 400$ million before he was detected. This was more than 95\% of Hollinger's adjusted net income (Coffee 2005:207). In Australia, KPMG and Deloitte were both sued by the Northern Territories Supreme Court for undisclosed millions for failing to detect the theft of millions of dollars by trustees of an Australian Aboriginal land trust whose accounts they audited (Wild 2014). And in the United States, a Senate subcommittee found that KPMG, PwC, and Earnst and Young had all sold fraudulent and illegal tax shelters to help wealthy clients avoid $\$ 2.5$ billion in taxes. KPMG admitted "criminal wrongdoing" to the Department of Justice and was fined \$456 million. However, the proceedings revealed that a senior KPMG professional had urged the firm to ignore internal revenue service rules on registering tax shelters. "He coldly calculated that the penalties for violating the law would be no greater than $\$ 14,000$ per $\$ 100,000$ in fees that KPMG would collect. 'For example', he wrote, 'our average . . . deal would result in KPMG fees of $\$ 360,000$ with a maximum penalty exposure of only $\$ 31,000$ "' (Hudson, Chavkin, and Mos 2014).

Such scandals have not dented KPMG's confidence in its own ethical probity and in the high standards of ethical conduct that it claims to require from its staff, as stated in its Global Code of Conduct (KPMG 2012b). Yet far from being anomalous, such calculations are central to the instrumental rationality of audit culture and the collusion that it produces. In some respects, this echoes Muir's observation about the moral ambiguity that surrounds corruption in Argentina; "people disavowed corruption in the same breath as they voiced their complicity with it" (Muir 2016:132). The growing entanglement of the Big Four in the business of universities creates new kinds of risk and complicity, and the evident conflicts of interest do not seem to deter university managers from seeking these firms' services in fraud prevention and anti-corruption.

\section{Conclusions: Performativity of Fraud and Anti-corruption}

These stories highlight both the financial logics and conflicts of interest at play in the activities of the Big Four accountancy 
firms. They also show how these firms collude in the risk and corruption that they claim to ameliorate, a process that illustrates the market-making potential of anti-corruption discourses: audit firms produce reports highlighting the dangers of fraud, for which they profess to offer the solution-to their fee-paying clients. As Sampson (2010) argues, this "anti-corruption industry" is both a growing transnational business and a "world" in the anthropological sense (Sampson 2005:110). It also reflects what Wedel (2009:51) terms the "dirty togetherness" of collision and collusion between individuals and corporate networks that operate in the gray zones and revolving doors between the private and public spheres. Universities should therefore be wary of contracting these commercial audit firms to run their services. This is not to trivialize the problem of corruption in universities or elsewhere but rather to interrogate the discourse of risk management, with its metaphors of icebergs and storms on the horizon, and ask whether these large accountancy firms are sufficiently independent to provide the necessary watchdog and guardian function to protect organizations against fraud and corruption. As the House of Commons Committee of Public Accounts (2015:6) concluded, the tax industry "has demonstrated very clearly that it cannot be trusted to regulate itself."

The stories also highlight two other points of wider relevance to debates about corruption and its remedy. The first concerns issues of ethics and morality. Expert opinion holds that corruption and fraud prevention are cultural and behavioral issues rather than systemic problems. As the UNESCO report concluded, the solution to fraud and corruption lies in enhancing "ethical education," "maintaining transparent regulatory systems," and "strengthening management capacities for greater accountability" - all of which will help to build a "virtuous triangle" (Hallack and Poisson 2007:21). However, in the case of KPMG US, corporate fraud and assisting clients with tax avoidance was not so much about morality as it was a simple business calculation (which, one could argue, is simply a different kind of economic morality). The issue for KPMG was not about ethics but about how much they could get away with without being caught and a calculation of the costs of being fined.

The second point concerns theories about the causes of corruption. The commonsense argument is that the root of corruption is individual avarice. As Colin Ferguson (2012:47) states, "simple greed and the opportunity to live beyond one's normal lifestyle are the primary motivations for fraud." This is sometimes framed as "good people doing bad things," an argument that lends support to calls for better training and guidance, which KPMG or Deloitte will provide. The examples in this paper tell a different story. They show that fraud and corruption are largely systemic and structural problems and that these have increased with the growing financialization and auditing of higher education. Strengthening management and subjecting universities to numerical performance targets and evergreater scrutiny and interventions by external assessors and auditors does not foster greater transparency or more ethical behavior. Indeed, these may produce the opposite effect by creating opacity, incentivizing more risky behavior, undermining collegiality, and promoting a regress of mistrust.

Substituting (or "supplementing") professional trust and collegiality with systems of audit is typically seen as a more rigorous and effective way to prevent corruption and promote ethical probity. This view is epitomized by New Zealand's Controller and Auditor General, Lyn Provost: "It is also important to remember that trusting staff is not a fraud control. Systems do not commit fraud, people do. Public entities need to ensure that they have the right systems in place" (Auditor General of New Zealand 2012:3).

This statement recalls the argument, often used by the US National Rifle Association, that "guns don't kill people, people kill people." The flaw in this reasoning is that it is systems that create the conditions of possibility and incentives for corruption. By blurring the distinction between public and private and encouraging the increasing incursion of private wealth accumulation into the public sphere, private audit companies actively collude in the neoliberal makeover of universities. Moreover, substituting professional judgment with auditing technologies tends to have a corrosive effect on relations of trust, particularly in the public sector, as O’Neill (2002) has argued. This kind of approach unwittingly destroys the very idea of the university itself as a place of disinterested scholarship and teaching, which has traditionally always relied on ideas of collegiality, professionalism, and trust.

This invites the question, why did Auckland University's Audit and Finance Committee contract out the administration of its fraud prevention program to KPMG Australia rather than deal with it in-house or with professionals who were not tied to the management and accounting industrysuch as Transparency International's long-standing Advocacy and Legal Advice Centres? ${ }^{8}$ Might it have had something to do with the composition of that committee, the fact that the chairman of the university's council was an accountant, or that the university's internal control environment is regularly audited by its internal auditors, PwC? At least the contract was not outsourced to $\mathrm{PwC}$, which might have been considered inappropriate. According to one informant, "the university went out to a limited tender, and KPMG was selected from amongst the various proposals." Coincidentally, one of the council members had been a partner for KPMG for 30 years and chair and chief executive of KPMG New Zealand from 2008 to 2011.

This brings us back to the anthropological point I began with about the wider definition and meaning of corruption and the way that privatization and the growing influence of commercial interests are changing (and corrupting) the meaning and mission of the university. Paradoxically, the institutionalization of antifraud programs is fuelling that process.

8. Transparency International's Advocacy and Legal Advice Centres have been providing free and confidential legal advice to witnesses and victims of corruption since 2003 (Transparency International 2016). 
Finally, it is important to note that no definition of fraud actually exists in the criminal code in Australia. The Australian Fraud and Corruption Control standard defines fraud as:

dishonest activity causing actual or potential financial loss to any person or entity including theft of money or other property by employees or persons external to the entity and whether or not deception is used at the time. . . This also includes deliberate falsification, concealment, destruction or use of falsified document used or intended for use for a normal business purpose or the improper use of information or position. ${ }^{9}$ (Ferguson 2012:48)

This is an extraordinarily broad definition and one that could also encompass activities and behaviors routinely performed by university vice chancellors and senior management teams, particularly in their dealings with academics or negotiations with staff unions. Indeed, tertiary education union members regularly spoke about management's tactical use of concealment, falsification of the facts, and improper use of information during the industrial disputes between 2010 and 2013 (Shore and Davidson 2014).

The issue of corruption in the university is therefore perhaps less problematic than the corruption of the university, particularly as this relates to the increasing capture of its assets by predatory financial interests and for-profit companies. Rosigno's polemic about university bureaucracy as organized crime may, in fact, be quite prescient: the harm to universities as a result of increasing extraction of income from parents and students, the endless reforms to transform universities into simulacra of the transnational business corporation, and the continuous administrative and managerial bloat certainly provide a broader perspective for thinking about the anthropology of corruption. If corruption is a "category of transgression," as Muir and Gupta (2018) note, then what we need are new concepts and methods to better understand what transgression means in a university and academic context. We used to think of corruption as the abuse of office or use of power for personal private gain, but the blurring of the boundaries between the public and private sectors and the revolving door between finance, accountancy, and the governing boards of public organizations has elided the distinction that once insulated the public sector from the predatory interests and logics of finance capitalism. I have singled out the role of the Big Four accounting firms as key agents in this boundary-eroding work, but they are not alone. Audit culture and the corruption potential it generates are part of a much larger complex of lean and mean organizations, the tasks that they are required to perform, the pressures that they are under, and the way they are managed.

9. New Zealand's Serious Fraud Office (2015) similarly defines fraud as "dishonest activity causing actual or potential financial loss to any person or entity, including theft of money or other property, by employees or persons external to the entity; and where deception is used at the time, immediately before or immediately following the activity."
Not even the Big Four are safe from audit culture and its rationale. After all, it was not so long ago that the Big Four were the Big Eight, then the Big Five. And the king of them all, Arthur Anderson, fell from grace in a way that no one, least of all the big accounting firms, expected.

\section{Acknowledgments}

I thank the Wenner-Gren Foundation for supporting my participation at the workshop in Sintra, where the ideas for this paper were explored and road tested; the other participants at that workshop; and Akhil Gupta and Sarah Muir, in particular, for organizing the workshop and this special issue of Current Anthropology. I also thank the two anonymous referees for their extremely detailed and helpful comments on an earlier draft of the article. I owe a special debt of gratitude to Steven Sampson for sharing with me his thoughts on my argument and his detailed knowledge and insights into the anticorruption industry, the rise of the compliance officer, and the emergence of ethical capitalism.

\section{References Cited}

Agnew, Harriet. 2015. Professional services: accounting for change. Financial Times, August 27. http://www.ft.com/cms/s/0/938ed6c6-36e6-11e5-bdbb -35e55cbae175.html\#axzz4CydXOsYw (accessed June 28, 2016).

Altbach, Philip. 2015. The question of corruption. International Higher Education 34:7-8.

Amsler, Mark, and Cris Shore. 2015. Responsibilisation and leadership in the neoliberal university: a New Zealand perspective. Discourse: Studies in the Cultural Politics of Education 38(1)123-137.

Auditor General of New Zealand. 2012. Fraud awareness, prevention, and detection in the public sector. Wellington, New Zealand: Office of the Auditor General.

Austin, John Langshaw. 1962. How to do things with words. Oxford: Clarendon. Australian Government. 2016. Anti-corruption. Attorney-General's Department web page. https://www.ag.gov.au/CrimeAndCorruption/AntiCorruption/Pages /default.aspx (accessed November 28, 2016).

Barber, Michael, Katelyn Donnelly, and Saad Rizvi. 2013. An avalanche is coming: higher education and the revolution ahead. London: Institute for Public Policy Research. http://www.studynet2.herts.ac.uk/intranet/lti.nsf/0 /684431DD8106AF1680257B560052BCCC/\$FILE/avalanche-is-coming_Mar 2013_10432.pdf.

Butler, Judith. 1997. Excitable speech: the politics of the performative. New York: Routledge.

Chapman, David, and Samira Lindner. 2016. Degrees of integrity: the threat of corruption in higher education. Studies in Higher Education 41(2):247268.

Coffee, John C., Jr. 2005. A theory of corporate scandals: why the USA and Europe differ. Oxford Review of Economic Policy 21(2):192-211.

Comaroff, John, and Jean Comaroff. 2006. Law and disorder in the postcolony. Chicago: University of Chicago Press.

Csordas, Thomas J., Helene Basu, Vincent Crapanzano, David Parkin, Amélie Rorty, Peter van der Veer, Pablo Wright, and Thomas Csordas. 2013. Morality as a cultural system? Current Anthropology 54(5):523-546.

Day, Michael. 2011. Family fiefdoms blamed for tainting Italian universities. Independent, October 23. http://www.independent.co.uk/news/world/europe /family-fiefdoms-blamed-for-tainting-italian-universities-2089120.html.

Deloitte. 2012. Deloitte bribery and corruption survey 2012 Australia and New Zealand: a storm on the horizon. Sydney: Deloitte.

Doherty, Raymond. 2014. Deloitte replaces PwC as biggest global firm. Economia, January 30. http://economia.icaew.com/news/january-2014/deloitte -replaces-pwc-as-biggest-firm.

Ernst and Young. 2013. Global code of conduct. http://www.ey.com/Publication /vwLUAssets/Ernst-Young_Global_Code_of_Conduct/\$FILE/EY_Code_of _Conduct.pdf (accessed October 1, 2017). 
Ferguson, Colin. 2012. Fraud in Australia. Insights 12(November):47-51.

Grove, Jack. 2015. Grant income targets set at one in six universities, THE poll suggests. THE, June 11. https://www.timeshighereducation.com/news /grant-income-targets-set-one-six-universities-poll-suggests (accessed May 24, 2016).

Hacking, Ian. 2002. Historical ontology. Cambridge, MA: Harvard University Press.

Hallak, Jacques, and Muriel Poisson. 2007. Corrupt schools, corrupt universities: what can be done? Paris: International Institute for Education Planning.

Heyneman, Stephen. 2013. Higher education institutions: why they matter and why corruption puts them at risk. In Global corruption report: education. Transparency International. Pp. 101-107. London: Routledge.

House of Commons Committee of Public Accounts. 2015. Tax avoidance: the role of large accountancy firms (follow-up). January 28. London: Stationery Office.

Hudson, Michael, Sasha Chavkin, and Bart Mos. 2014. Big 4 audit firms play big role in offshore murk. International Consortium of Investigative Journalism, November 5. http://www.icij.org/project/luxembourg-leaks/big-4 -audit-firms-play-big-role-offshore-murk/ (accessed February 24, 2015).

Independent Financial Review. 2010. Fraud up. Independent Financial Review, February 18, business sec., 2. http://www.knowledge-basket.co.nz.ezproxy.auck land.ac.nz/databases/newztext-uni/search-newztext/view/?sid $=1526139 \& d$ $=$ magz/text $/$ ind $/ 2010 / 02 /$ IFR1002180002123806100-AN.html (accessed February 24, 2015).

KPMG. 2010. Fraud and misconduct survey 2010: Australia and New Zealand. Sydney: KPMG.

. 2012a. Fraud barometer. 7th ed. Wellington, New Zealand: KPMG NZ Forensic.

- 2012b. KPMG global code of conduct. KPMG International. https:// assets.kpmg.com/content/dam/kpmg/pdf/2012/10/code-of-conduct-2012v2 .pdf (accessed October 1, 2017).

_.2016. Climate change and sustainability services. https://home.kpmg.com /au/en/home/services/advisory/risk-consulting/climate-change-sustainability-ser vices.html (accessed November 29, 2016).

KPMG Australia. 2016a. Profiles of the fraudster: technology and weak controls fuel fraud. https://home.kpmg.com/xx/en/home/insights/2016/05/global-profiles -of-the-fraudster.html (accessed October 11, 2016).

- 2016b. Whistleblower reporting service: FairCall. https://home.kpmg .com/au/en/home/services/advisory/risk-consulting/forensic/faircall.html (accessed November 28, 2016)

KPMG New Zealand. 2012. Fraud, bribery and corruption survey. Wellington, New Zealand: KPMG. https://www.kpmg.com/NZ/en/IssuesAndInsights /ArticlesPublications/Documents/Fraud-Bribery-and-Corruption-Survey-2012 .pdf.

Lewis, Nicolas, and Cris Shore. 2017. Managing the third mission: reform or reinvention of the public university? In Death of the public university? S. Wright and C. Shore, eds. Pp. 47-64. Oxford: Berghahn.

Marginson, Simon, and Mark Considine. 2000. The enterprise university: power, governance and reinvention in Australia. Cambridge: Cambridge University Press.

McEntee, Claire. 2010. Large fraud tops \$72m in 6 months. Stuff, July 19, business sec. http://www.stuff.co.nz/business/3930783/Large-fraud-tops-72m-in-6-months (accessed June 9, 2016)

Muir, Sarah. 2016. On historical exhaustion: Argentine critique in an era of "total corruption." Comparative Studies in Society and History 58(1):129158.

Muir, Sarah, and Akhil Gupta. 2018. Rethinking the anthropology of corruption: an introduction to supplement 18. Current Anthropology 59 (S18) S4-S15.

O'Neill, Onora. 2002. A question of trust: the BBC Reith Lectures of 2002. Cambridge: Cambridge University Press.

Osipian, Ararat. 2008. Corruption in higher education: does it differ across the nations and why? Research in Comparative and International Education 3(4):345-365.

. 2009. "Feed from the service": corruption and coercion in stateuniversity relations in Central Eurasia. Research in Comparative and International Education 4(2):182-203.

Parkin, David. 1985. Introduction. In The anthropology of evil. D. Parkin, ed Pp.1-25. Oxford: Blackwell.

Parr, Chris. 2013. Rising university corruption linked to falling public investment. Times Higher Education, October 3. https://www.timeshighereducation.com /news/rising-university-corruption-linked-to-falling-public-investment/2007868 article.
Perotti, Roberto. 2008. L'università truccata: gli scandali del malcostume accademico, le ricette per rilanciare l'università. Rome: Einaldi. http://www .lavoce.info/archives/25202/luniversita-truccata/.

Power, Michael. 1997. The audit society: rituals of verification. Oxford: Oxford University Press.

PwC (PriceWaterhouseCoopers). 2014. Economic crime: what you don't know can hurt you: New Zealand supplement. http://www.pwc.co.nz/PWC.NZ/media /pdf-documents/publications/pwc-global-economic-crime-survey-new-zealand -supplement-feb-2014-final2.pdf (accessed June 12, 2016).

Roscigno, Vincent. 2015. University administration as organised crime. CounterPunch, August 4. http://www.counterpunch.org/2015/08/04/university-bureau cracy-as-organized-crime/.

RNZ (Radio New Zealand). 2010. Fraud expected to rise to record level. Radio New Zealand, July 19. http://www.radionz.co.nz/news/business/44434/fraud -expected-to-rise-to-record-level.

2 2011. Fraud prosecutions by SFO jump by a third. Radio New Zealand, March 28, 2011. http://www.radionz.co.nz/national/programmes /morningreport/audio/2477493/fraud-prosecutions-by-sfo-jump-by-a-third. Sampson, Steven. 2005. Integrity warriors: global morality and the anticorruption movement in the Balkans. In Corruption: anthropological perspectives. D. Haller and C. Shore, eds. Pp 103-130. London: Pluto.

2010. The anti-corruption industry: from movement to institution. Global Crime 11(2):261-278.

. 2016. The "right way": moral capitalism and the emergence of the corporate ethics and compliance officer. Journal of Business Anthropology 2 (1):65-86.

Scoop Media. 2010. Fraud rises to record levels in New Zealand: KPMG. Scoop, February 15. http://www.scoop.co.nz/stories/BU1002/S00382/fraud -rises-to-record-levels-in-new-zealand-kpmg.htm.

Serious Fraud Office of New Zealand. 2015. What is serious fraud? Auckland: Serious Fraud Office. https://www.sfo.govt.nz/what-is-serious-fraud.

Shore, Cris. 1989. Patrons, bureaucrats and the nation-state: social relations in an Italian university. Journal of the Anthropology Society of Oxford 20(1): $56-73$.

- 2008. Audit culture and illiberal governance: universities and the politics of accountability. Anthropological Theory 8(3):278-298.

Shore, Cris, and M. Davidson. 2014. Beyond collusion and resistance: academicmanagement relations within the neoliberal university. Learning and Teaching 7(1):12-28.

Shore, Cris, and Dieter Haller. 2005. Sharp practice: anthropology and the study of corruption. In Corruption: anthropological perspectives. D. Haller and C. Shore, eds. Pp. 1-26. London: Pluto.

Shore, Cris, and M. Taitz. 2012. Who owns the university? institutional autonomy and academic freedom in an age of knowledge capitalism. Globalisation, Societies and Education 10(2):201-219.

Shore, Cris, and Susan Wright. 1999. Audit culture and anthropology: neoliberalism in British higher education. Journal of the Royal Anthropological Institute 7(4):759-763.

. 2015. Audit culture revisited: rankings, ratings and the reassembling of society. Current Anthropology 56(3):421-439.

, eds. 2017. Privatising the public university: key trends, countertrends and alternatives. In Death of the public university? S. Wright and C. Shore, eds. Pp. 1-27. Oxford: Berghahn.

Sikka, Prem. 2014. The corrosive effects of neoliberalism on the UK financial crises and auditing practices: a dead-end for reforms. Accounting Forum 39: $1-18$.

2015. Accounting for corruption in the big four accountancy firms. In How corrupt is Britain? D. Whyte, ed. Pp. 157-167. London: Pluto.

Slaughter, Sheila, and Larry Leslie. 1997. Academic capitalism: politics, policies, and the entrepreneurial university. Baltimore, MD: Johns Hopkins University Press.

Stiglitz, Joseph. 2010. Freefall: free markets and the sinking of the global economy. London: Lane.

Strathern, Marilyn, ed. 2000. Audit cultures: anthropological studies in accountability ethics and the academy. London: Routledge.

Thompson, Lisa. 2010. Fraud rises to record levels in NZ according to KPMG report. Radio NZ Newswire, February 15. http://www.knowledge-basket.co.nz .ezproxy.auckland.ac.nz/databases/newztext-uni/search-newztext/view/?sid $=1526137 \& \mathrm{~d}=\mathrm{rnz} / \mathrm{text} / 2010 / 02 / 14 / 72884 \mathrm{e} 8 \mathrm{html}$ (accessed June 7, 2016).

Transparency International. 2013a. Global corruption report: education. London: Routledge.

. 2013b. Global corruption report: education (interactive report). http:// www.transparency.org/gcr_education (accessed June 6, 2016). 
2016. Our work on whistleblowing. http://www transparency.org/what wedo/activity/our_work_on_whistleblowing (accessed June 10, 2016).

Turner, Victor. 1988. The anthropology of performance. New York: PAJ.

UoA (University of Auckland). 2010. The prevention of fraud and corruption policy. University of Auckland internal staff document. Auckland: University of Auckland.

2014. Confidential staff hotline continues. University of Auckland staff website. https://www.staff.auckland.ac.nz/en/news-events-and-notices /news/news-2014/05/Confidentialhotline.html (accessed November 30, 2015).

Wedel, Janine. 2009. Shadow elite: how the world's new power brokers undermine democracy. New York: Basic.

Whyte, David. 2015. Introduction: a very British corruption. In How corrupt is Britain? D. Whyte, ed. Pp. 1-38. London: Pluto.
Wild, Kate. 2014. KPMG denies role in alleged theft from Australia's richest Aboriginal land trust. ABC News, November 11. http://www.abc.net.au/news /2014-11-11/kpmg-denies-role-in-alleged-theft-from-groote-eylandt-land-trust 15882920.

World Bank. 1997. Helping countries combat corruption: the role of the World Bank. Washington, DC: World Bank Poverty Reduction and Economic Management Network.

Wright, Susan, and Cris Shore, eds. 2017. Death of the public university? un certain futures for universities in the knowledge economy. Oxford: Berghahn. Yang, Rui. 2015. Corruption in China's higher education: a malignant tumor. International Higher Education 39(March 25):18-20.

Zinn, Dorothy. 2001. La raccomandazione: clientelismo vecchio e nuovo. Rome: Donzelli Editore.

This content downloaded from 158.223.166.040 on March 15, 2019 04:34:01 AM 